\title{
Usability of Software of Teaching Aid in the Teaching Process Mathematics Learning
}

\author{
Tiago Soares dos Reis, Rafael Correia Miranda, Albano Dias Pereira Filho
}

\begin{abstract}
This work is the result of a research that aimed to identify the teaching aid software for Mathematics applied to High School. Aiming to analyze the use of software as a teaching tool in the State of Tocantins. And from this perception inferred which programs are most used and the respective school years. In this way, the present article presents in its constitution the presentation of teaching aid software for Mathematics applied to High School, cited and used by the teachers participating in the research. The result showed that there are several software available, however, there is a lack of incentives for teachers to use them. It was also evidenced that educators consider the use of technological tools, as providers of positive impact in the teaching-learning process of Mathematics.
\end{abstract}

Index Terms-Software, mathematics, teacher, student, education.

\section{INTRODUCTION}

Currently, a study carried out with the Ministry of Education (MEC), the body that regulates education in Brazil, emphasizes that basic education should be divided into stages, with secondary education completing these, and may or may not be offered integrated into a technical course, lasting from three (3) to four (4) years.

The approval [1], in the 90's, called secondary education of non-compulsory secondary education and aimed at young people between the ages of 15 and 17 graduating from elementary school. This stage started to have a single structure throughout the national territory, undergoing structural changes over the years.

Their goal was not only to teach the content to the student, but also to provide the general training of the young individual with basic knowledge and skills for life. The [2] defines High School as "... the final stage of Basic Education, subjective public right of every Brazilian citizen".

Despite the modifications in High School continues with some of its primary goals. Such as, the possibility of being enrolled in the Youth and Adult Education Mode (EJA), or even in the normal modality plus a vocational technical course. The EJA allows the student to study two series in a single year, thus being able to complete high school in a period of one year in between. In the integrated modality to a technical course a year is added, thus, going from a three to four year duration [3].

According [4] since its creation, High School has undergone several reformulations. These reforms permeated

Manuscript received November 12, 2018; revised March 12, 2019.

The authors are with Instituto Federal do Tocantins, IFTO, Brazil (e-mail: tsoaresdosreis@gmail.com,

albano.filho@ifto.edu.br). the pillar of the initial project that had previously only the job of preparing the individual for the labor market. Nowadays, the function of this stage of education is also to prepare the individual as a human being, in a way in which both his or her personal development and social development are promoted, showing him the possibility of questioning and positioning himself on the hegemony of nations that hold the power of scientific-technological knowledge.

However, this is considered to be the information age, so it arises from the need of the high school teacher as well as teachers from previous and later stages not only to teach content but to prepare the individual to deal with the large number of information every day they are presented to you.

In this way, the school environment was previously confined to the classroom and the bibliography used. Thus, the teacher's rhythm predetermined the learning of his students. With the emergence of technological tools, this scenario has changed and the student can control the pace or even promote his own learning. Thus, the role of the teacher has changed, not with the purpose of determining what the learner should learn, but of guiding the learner in his / her learning process [5].

Returning a few years in history, it turns out that education was limited only to a formal, classroom setting in the classroom, where only a chalkboard and chalk were used. The teacher seemed to hold the absolute truth which conveyed authoritative information while the student assumed a quiet role in the educational process. However, there is currently an attempt of the school to relate to democratization from the act of educating, in which the student's interaction interferes in his own teaching and learning process, in this model the teacher acquires the role of guiding and the student becomes have its uniqueness [5].

Still, corroborating with the studies done by [5], [6] discusses that technologies have caused the world to undergo a process of constant modification. This fact also modifies the school environments. Faced with these transformations, it is up to the teacher to adapt to the new scenario that changes day after day, through the insertion of Information and Communication Technologies (ICTs) in school environments, considering that these serve as facilitating strategies in the teaching-learning process, adding theory and practice, often in a playful way, thus leading to greater interaction between students and content.

For [7] students learn to feel challenged, when they have the need or interest in something. With the help of technologies this becomes more feasible, given that the educational software of the game mode is a way to challenge the student and many contents become more interactive through the World Wide Web. 
For France and [8] if the teacher has the "qualities of a good educator" he is able to learn from the learner. According to Pinheiro, Silveiro and Bazzo (2007) [9], when teachers and students use TICs together, they discover and construct learning, obtaining scientific knowledge, which is no longer considered as the only truth, since scientific research undergoes several modifications. This is because the information is available through computer networks, however it is necessary that the student understands that even having such a large amount of content at his disposal, using it is still subject to criticism and reformulations. In this way, the student and the teacher together construct the structure of knowledge.

For [10] technological advances have been responsible for offering various tools that spread communication and knowledge via the internet to those who use the media in general. [11] states that technologies transform the way humans think, feel and act. Garcia also affirms that man can also transform himself with the communication of people, thus changing the way of communicating and acquiring knowledge. [12] argues that the school environment when mediated by technologies stimulate student curiosity and improve performance in terms of abstraction of the content worked.

When doing an analysis of the current context of society, it is necessary to analyze everything that was reflected above in parallel with the current teachers of Mathematics of the High School in the state in Tocantins, investigating if they are using some software as a tool to aid teaching, and if they are the tools most used by these teachers.

Therefore, this research has as main objective to identify the existing software to aid the teaching of Mathematics, to investigate if the teachers are using these tools of teaching support and to point out on a degree to scale the usability of each of them. Regarding the specifics, the work addresses the following: Identify the software to aid teaching of Mathematics applied to High School; Find out if high school mathematics teachers are using software as a teaching aid tool and point to a scalar grade which are the most used software.

When raising a hypothesis of the questioning that made possible the writing of this work, it was considered that there are several software to aid teaching of Mathematics applied to High School, a portion of which has a high degree of usability, but many are not handled by teachers.

For the accomplishment of this research, it was necessary to elaborate 5 (five) great topics, in order to better describe the stages used. The topic in which it received the denomination introductory procedures began, in this one it is approached education of the High School and the use of the TICs, besides the objectives, problematic and hypothesis of the research. In the second stage, a study of the theoretical references is presented, with the purpose to base the knowledge on the subject to guarantee continuity, as well as to facilitate the theoretical basis in the moment of the analysis of the collected data.

The third is a detailed description of the steps taken during the course of the research, as well as describing the materials used to carry it out, that is, the Methodology. Following is the topic that describes the results obtained during the research.
The fifth and last topic, but not least, consists of the Final Considerations, in which the results achieved with the respective research are present, besides showing the necessity of some other studies that continue the theme.

When developing this work it was observed that there are several softwares with the purpose of assisting the teacher of Mathematics in High School. However, not everyone has acceptance in this market. It was also noticed that teachers use such technologies, since all the respondents cited at least one software as being used in their teaching work.

\section{Software in MAthematics LeARNing: A BRIEF Cutout}

The use of teaching aid software in Mathematics has been studied by several researches in recent years. With this, works like that of [13]-[20] show that these tools are of great value to the teaching of Mathematics.

About the teaching aid software in Mathematics, [21] in his work had as purpose to analyze the use of the Kahoot application as evaluation and teaching-learning tool in the teaching of industrial microbiology, reports that the students cited the competition as a way of stimulation of learning. The students also mentioned that "Kahoot can be used as a substitute for traditional assessment", this is because the use of the application makes it "possible to reach different levels of complexity" and these in turn challenge the student to make learning more efficient and lasting.

In a study carried out by a group of undergraduate students from the Integrated Regional University of Alto Uruguay and the URI Missions [22], the purpose of which was to use GeoGebra as a tool to help the high school teacher, it was concluded that importance of the use of softwares that help the teacher in the classroom. This is because "in addition to being a differentiated methodology that attracts attention and concentration of students, it still allows for a better graphic visualization, which students often do not have through the traditional way."

In a study about the use of technologies in the learning process, [23] can see that the use of digital tools in this process is capable of modifying the way in which the student learns, leading to a greater degree of attention teacher and, consequently, having more learning.

\section{A. Educational Trends in the XXI Century}

Ref. [24] defines pedagogical practices as the way in which teachers select and organize contents and materials from different disciplines, as well as the way of teaching and evaluating learning.

José Carlos Libâneo also affirms that teachers take over different types of pedagogical practices and that in the vast majority "base their practice on pedagogical prescriptions that have become common sense, incorporated when they pass through the school or transmitted by their older colleagues" [24]. However there are cases of teachers who are not part of this group, are those "able to perceive the broader meaning of their practice and to make explicit their convictions." There is still a third group, those who totally take ownership of innovative practices, without any kind of reflection being made if such pedagogical practices have a 
positive effect on the reality in which it is inserted.

Coming to meet the goals of the High School dictated by the MEC, Libane says that the role of the school should be to meet the individual needs in their social environment. This in turn carries as an obligation the preparation of the student for life.

Thus, because the teacher is the member of the school that has the greatest direct contact with the student, we can reach the conclusion that their practices are the major responsible for the success or failure of teaching and learning. However, he must always be attentive to his pedagogical practices, so that he has a balance between the traditional and the radicalism of innovative practices, being always in balance with the coexistence and respect of both parties, in the teacher-student environment, taking into account which implies the success or failure of teachers 'pedagogical practices and consequently their students' learning [24].

\section{Methodological Procedures}

In order to follow the proper paths of scientific research and writing standards of the Portuguese Language, the present work was based on the teachings of [25], with respect to the method chosen to carry out the research was the hypothetical inductive, because the intention was to represent in an integrated way the answers given by the public surveyed. After choosing the methodology that was adopted to carry out this research, it was necessary to start the studies from the following steps, described below.

The first step developed for the accomplishment of this work was the bibliographical survey of existing software available for use by teachers of the modality High School, where 154 (one hundred and fifty four) software were identified with the respective purpose and focused on the area of mathematics. All of these were found available for free at governmental and non-governmental educational websites. These were listed, with the intention of identifying the main programs of aid to the teaching of Mathematics next to High School.

The second stage, with the purpose of complementing the theoretical basis of the research, made it necessary to search in the literary clippings, works related to the elaboration, but in other fields of research. In order to do this, the search terms were defined, ie, the key words: technologies, use, education, high school and educational software, aiming to facilitate the localization of articles, theses, dissertations and books in the computer network that may contribute to the evolution of the writing of this work. After defining the terms, the database to be used is ACM Digital Library, portal, ScienceDirect, Elsevier IEEE Xplore and Emerald and Google Scholar and Microsoft Academic, ISI Web of Science, Wiley InterScience and CAPS Portal Periodicals, because they are bases that have a higher degree of confidence of the available works. Subsequently, the search terms were applied to the databases defined and selected based on themes and summaries of the journals suggested by the platforms that contributed to the bibliographic reference.

Subsequently the research questionnaire was elaborated. In order to obtain the best possible way, the questionnaire was prepared in Google Docs, which is part of the package of the Google Drive platform, in this way it was possible for the respondents to contribute with the present research without the geographical displacement, both by the researcher and the researcher. Once the survey questionnaire was done, a poll called a validation questionnaire was also prepared on the same platform, aiming to evaluate the clarity and objectivity of the previously created questions. However, the research also allowed the participation of professors with other teaching links, that is, of another type of educational institution, which could choose to identify or not to participate in the study. situation, being thus able to choose by which type of institution it would wish to contribute with the research.

After the questionnaires were sent by e-mail to 50 (fifty) teachers, he listened to a 15 (fifteen) day wait, during which time eight (8) responses were obtained regarding the validation of the questionnaire. From then on the questionnaire was changed based on a single suggestion that was given by a researcher. Subsequently, the research questionnaire was submitted.

With the questionnaire validated the official collection of the responses was started, this process lasted for 7 (seven) months, with the first response in the period of 08/29/2016 and the last in $03 / 20 / 2017$. These responses were all obtained online using the Google Drive platform, with the researchers emailing the questionnaire link and the invitation to collaborate with the survey and the respondents in their time collaborated with the questions. 1,200 teachers were asked to collaborate with the research, of which 37 (thirty-seven) answers were obtained from mathematics teachers. These are located geographically separated, but all in municipalities of the State of Tocantins.

With the answers obtained the data was tabulated, this step consisted in exposing the data in tables, standardizing the answers so that it became possible to demonstrate them in the form of graphs. Providing a better understanding for the reader of the present work. After the tabulation, individual graphs were elaborated, in which the answers of each question present in the questionnaire are shown. After this completed step, the written part was started, in which this article became possible.

\section{RESUlts AND DiscUSSIONS}

The survey had respondents from several cities in the state of Tocantins, a total of 23 (twenty-three), of which the most obtained was Porto Nacional, the fourth largest city in the state that contributed 5 (five) respondents. Following was the city of Araguaína with 4 (four) respondents and Palmas, the state capital with 3 (three) respondents. The other cities that had teachers participating in the research were responsible for quantitative values between 2 (two) and 1 (one) respondent. Fig. 1 shows the cities that had teachers collaborating with the research.

Teachers were asked about their employment relationship at the time they answered the questionnaire, most of them said they had a link with the State Education Network, 77\% (77 per cent). The private initiative presented less attention by the teachers when asked what the employment relationship, showing that only $2 \%$ (two per cent) of notes by 
the teachers.

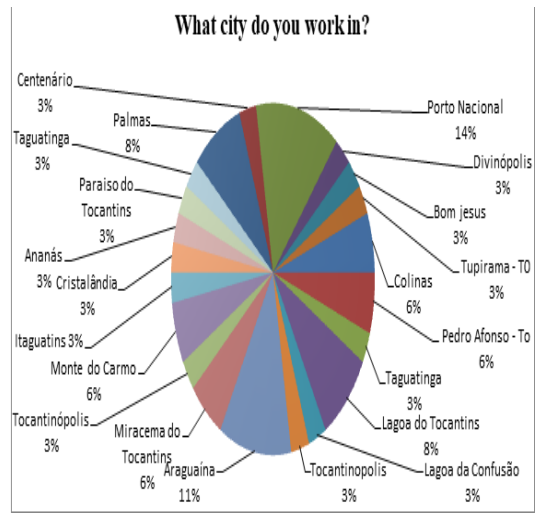

Fig. 1. The cities that had research collaborators. Source: Authors, 2018.

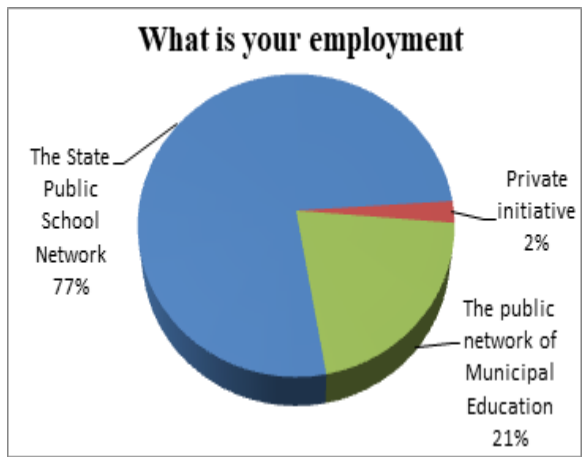

Fig. 2. Employee employment bond with research. Source: Authors, 2018.

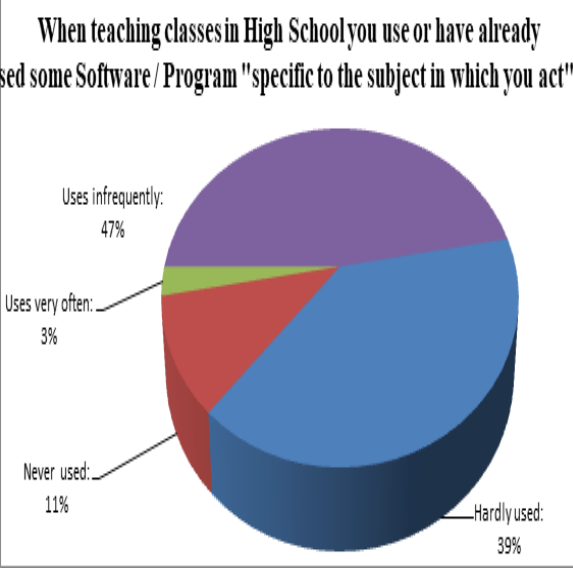

Fig. 3. Frequency of use of software. Source: Authors, 2018

\section{How do you evaluate the use of Educational Software} as a teaching aid tool in High School?

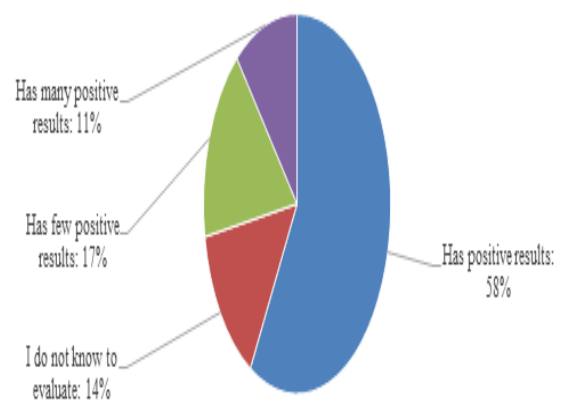

Fig. 4. Softwares pointed out as being most used by teachers. Source: Authors, 2018

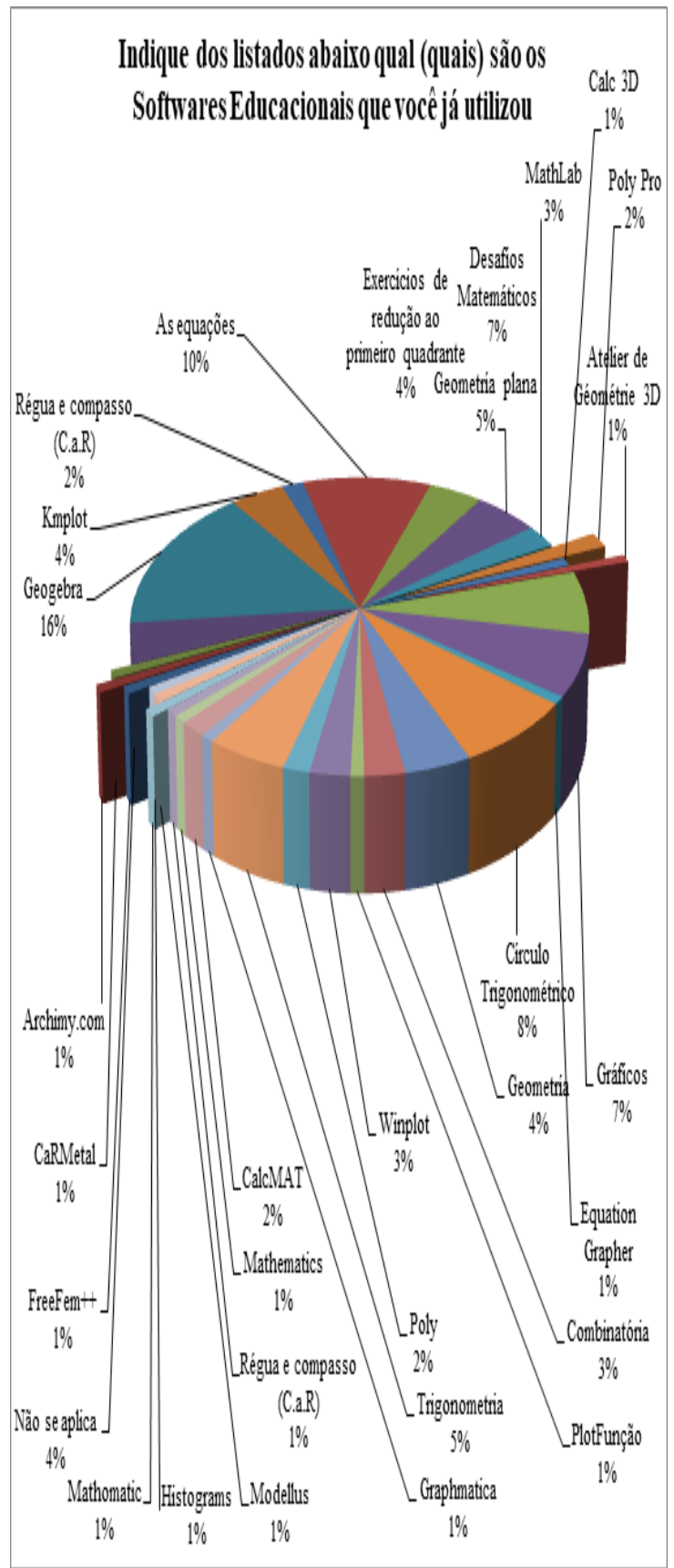

Fig. 5. Evaluation of the result caused by the use of specific software in the classroom.

Source: Authors, 2018.

In order to achieve the objectives of the research, it was necessary to consult the teachers who have used or have used in the last two years some specific teaching aid software in the classroom of Mathematics for high school students, in the whole $47 \%$ per hundred) reported using infrequently. Thus, it was the degree of usability that was more pointed out by the teachers, 39\% (ink and nine per cent) of the interviewees said that they hardly use software in their classes. While only $3 \%$ (three per cent) of the teachers surveyed said they use these programs very often.

Afterwards, it was questioned to those who stated to use what are the software they use. The software that had the most use was the Geogebra being pointed out by more than half of the total of the interviewees. Following, the software The Equations with 12\% (twelve) teachers, Mathematical Challenges and Graphs were the software that had (eight) notes. The other programs had between 1 and 7 teachers who 
spoke have already used them and 5 (five) of them did not indicate which programs they use.

All the public surveyed stated that the use of mathematics softwares to aid teaching in the classroom has a positive effect on student learning. He pointed out $58 \%$ (fifty-eight per cent) claimed positive results and $11 \%$ (eleven per cent) claimed to add many positive results.

When asked how teachers evaluate the practice of using classroom teaching aid software, only one teacher said that they do not know how to evaluate.

\section{FINAL CONSIDERATIONS}

The research allowed the perception of the existence of a high range of software to aid teaching in the discipline Mathematics applied to High School. Thus, based on the teachers' responses, it was concluded that they use computer education programs, but on a low scale, with little variety of software that meets the requirements of teachers, because although there are many available educators infer that basically use the same software, and there is no great demand for different programs.

When comparing the list of existing software with the teachers' responses, it was possible to observe that there are many programs available, but for some variable not analyzed in this research, the list of softwares frequently used by educators is small, that is , half of the participants $50 \%$ (fifty percent).

In this preamble the validation of the initial hypothesis of the research was verified, since specific softwares were found to aid the teaching of Mathematics in High School and verified in the answers of the collaborators that despite the teachers use these programs, few fulfill the requirements that the investigated professionals need so few programs are said to have usability by the respective teachers.

In this way, it is concluded that the present work contributes to education and suggests the development of related technologies in the educational field, having as justification a role of paramount importance for the learning of theoretical contents with playful and practical applicability.

The need for softwares with applications requested by the final public, which are the teachers and students of the area, also indicates the realization of future researches that may indicate the real reason for the few software used by the teachers. view that there are more than 150 (one hundred and fifty) available in the world-wide computer network and less than 50 (fifty) are cited as a methodological tool among the teachers questioned.

\section{REFERENCES}

[1] BRASIL, "Lei de Diretrizes e Bases da Educação Nacional: lei n 9.394 , de 20 de dezembro de 1996, que estabelece as diretrizes e bases da educação nacional,” Brasília: Câmara dos Deputados, Edições Câmara, 2012.

[2] BRASIL, "Ministério da Educação. Secretaria da Educação Básica," Base Nacional Comum Curricular, Brasília, DF, 2016.

[3] N A. M. PINHEIRO et al., Tecnologia E Sociedade: A Relevância Do Enfoque Cts Para O Contexto Do Ensino Médio. Paraná, 2007.

[4] S. Moehlecke, "O ensino médio e as novas diretrizes curriculares nacionais: entre recorrências e novas inquietações," Rio de Janeira. 2012.
[5] M. F. O. ELIA, Papel do Professor diante das Inovações Tecnológicas. Rio de Janeiro, 2014.

[6] J. G. Silva, "Novos cenários educacionais: políticas educativas transnacionais, formação de professores, tecnofobia e tecnofilia," Simpósio Internacional de Educação e Comunicação-SIMEDUC, no. 7, 2016.

[7] S. Scherer and G. S. BRITO, "Educação a distância: possibilidades e desafios para a aprendizagem cooperativa em ambientes virtuais de aprendizagem," Curitiba, 2014.

[8] R. P. SOUSA et al., "Teorias e práticas em tecnologias educacionais," Campina Grande, 2016.

[9] N. A. M. PINHEIRO et al., "Disponível em," 2007.

[10] F. F. França and G. Souza, "Quem ensina também aprende: a formação pela prática de professores primários na província do Paraná," Paraná, 2018.

[11] F. W. Garcia, "A importância do uso das tecnologias no processo de ensino-aprendizagem," Batatais, 2013.

[12] F. C. M. Andrade and R. P. Souza, "Modelos de Rotação do Ensino Híbrido: estações de trabalho em sala de aula invertida," Florianópolis, 2016.

[13] C. C. SANT'ANA et al., "Uso de softwares na prática profissional do professor de matemática," Ciência \& Educação, Bauru, vol. 18, no. 3 , pp. 527-542, 2012.

[14] S. Isotani and L. O. Brandão, "O papel do professor e do aluno frente ao uso de um software de geometria interativa: iGeom," BOLEMA, vol. 27, no. 45, pp. 165-192, 2013.

[15] M. M. Lopes, "Sequência didática para o ensino de trigonometria usando o software GeoGebra," BOLEMA, Rio Claro, vol. 27, no. 46, pp. 631-644, 2013.

[16] J. A. D. Pacheco and J. V. O. BARROS, "Uso de softwares educativos no ensino de matemática. Revista Diálogos," Pernambuco, no. 8, pp. 5-13, 2013.

[17] B. S. TOLEDO, "O uso de softwares como ferramenta de ensino aprendizagem na educação do ensino médio/técnico no Instituto Federal de Minas Gerais," Projetos e dissertações em sistemas de informação e gestão do conhecimento, vol. 3, no. 2, 2014.

[18] S. A. Xavier et al., "Uma proposta de ensino-aprendizagem das leis dos senos e dos cossenos por meio do software Régua e Compasso," Jornal Internacional de Estudos em Educação Matemática, vol. 7, no. 3, pp. 158-190, 2014.

[19] J. A. Macêdo et al., "Objetos de aprendizagem no estudo de tópicos de Matemática," Revista Tecnologias na Educação, vol. 7, no. 13, pp. 1-10, 2015.

[20] T. M. Oliveira et al., "Quebrando paradgimas no ensino da Matemática: um relato de experiência no (pro) EJA utilizando o software tux of math command," Revista Tecnologias na Educação, vol. 7, no. 13, pp. 1-10, 2015.

[21] D. SANDE, "O uso do Kahoot como ferramenta de avaliação e ensino-aprendizagem no ensino de microbiologia industrial," Salvador, 2018.

[22] T. M. Conrad, et al., "O Software Geogebra como Ferramenta de Auxílio no Ensino de Geometria," 2014.

[23] A. B. C. PEREIRA, "Uso de Jogos Digitais no desenvolvimento de competências curriculares da matemática," Teses de Doutorado. São Paulo, 2017.

[24] J. C. Libâneo, "Tendências pedagógicas na prática escolar," São Paulo, 2014.

[25] M. A. marconi and E. M. Lakatos, Fundamentos de metodologia científica, São Paulo: Atlas, 2003.

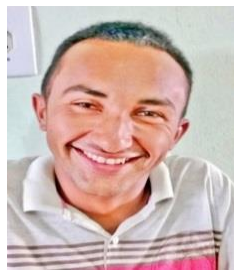

Tiago Soares dos Reis was born Brazil in 1989. He was awarded a degree in computer science in 2016 by the Federal Institute of Education, Sciences and Technologies of Tocantins. He specialized in teaching higher education in 2017 by Faculdade Suldamerica. Currently, he is teacher of EBTT at the Federal Institute of Education, Sciences and Technologies of Tocantins, Brasil.

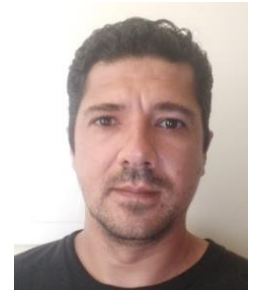

Rafael Corrreia Miranda was born on January 19 1981 in the city of Pedro Afonso - Tocantins - Brazil, where he lived until he was 18 years old. He completed basic education in 1999 in Brasília Federal District, Capital of Brazil, where he resided for only two years. Still in 2000 he moved to the city of Palmas, Capital of Tocantins - Brazil, where he carried out his studies. Graduation in Computer Science by the Institute of Teaching and Research 
Objective - IEPO (2007), post-graduations lato sensu in face-to-face format in: Public Management (2009) '; Teaching of Higher Education (2010) ${ }^{2}$, both by the Instituto Tocantinense de Pós-Graduação - ITOP; Lato sensu postgraduate course in Distance Learning $(\mathrm{EaD})$ taught in partnership with the Open University of Brazil (UAB) in Health Informatics by the Federal University of São Paulo - UNIFESP (2010) ${ }^{3}$ e Master in Computational Modeling of Systems by the University Federal of Tocantins - UFT (2015).

He joined the teaching profession in 2010 , where he was motivated by the teaching contest of the federal education network and lived for a year in the city of Araguatins - Tocantins - Brazil, in 2011 he was able to transfer the competition to Porto Nacional - Tocantins - Brazil where resides until the present moment giving classes of computation and concomitantly since 2016 coordinates the superior course of Degree in Computing.

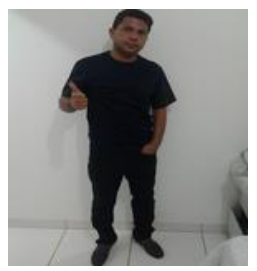

Albano Dias Pereira Filho was born in Nativity, State of Tocantins, BA in mathematics from the Lutheran University Center of Palms CEULP-ULBRA (2004). He specialized in mathematical education, Federal University of Tocantins UFT (2006). He is also specialized in School Assessment in mathematics by Foundation Cesgranrio (2009). He got the master's degree in science and mathematics teaching by University Lutheran of Brazil ULBRA de Canoas (2012); the PhD in mathematics education, University Anhanguera de São Paulo (2018). He is teacher of mathematics in the Technical Courses Integrated to High School, teacher of mathematics and statistics in the degree in computer science and teacher of applied statistics in the Superior Course of Logistics of the Federal Institute of Education, Science and Technology of Tocantins (IFTO) - Campus Porto. Institutional Coordinator of the Pedagogical Residency Program - IFTO. Member of the Chair of the Permanent Commission of Teaching Personnel - CPPD and Chairman of the Evaluation Committee. 